\title{
Holistic Vision of Sustainability in the Production Chain in Oil Exploration Pre-Salt Layer
}

\author{
Alessandro Luiz da Silva ${ }^{1}$, Mônica Franchi Carniello ${ }^{2}$, \\ and José Luís Gomes da Silva ${ }^{3}$ \\ 1,2,3 Universidade de Taubaté (UNITAU), \\ Programa de Pós-Graduação em Administração, Brasil \\ ${ }^{1}$ Mestre em Planejamento e Desenvolvimento Regional, UNITAU, Brasil \\ ssilengenharia@gmail.com \\ ${ }^{2}$ Doutora em Comunicação e Semiótica, Professor, UNITAU, Brasil \\ monicafcarniello@gmail.com \\ ${ }^{3}$ Doutor em Engenharia Aeronáutica e Mecânica, Professor, UNITAU, Brasil \\ gomesdasilvaster@gmail.com
}

\begin{abstract}
The current discussions about the future, especially considering the development has been promoting socio-joint policy in favor of sustainable growth, with relevance to the thoughts of Ignacy Sachs, which emphasizes the perspectives, social, economic, geographic, environmental and sustainability cultural. Thus, a holistic view, such perspectives on aspects of sustainability in the supply chain of oil in pre-salt layer, which has been widely discussed, especially in the scientific community. The research methodology is presented as qualitative and descriptive through literature review. Considering the problems wrapped exploration and logistics, and the magnitude in environmental, spatial, cultural, economic and social, we really prepared? As a result, we found basic technological gaps, as since its discovery in 2006, the pre-salt layer of Brazil and, especially, its operation is highly complex, requiring high costs of research and technological development, especially in innovation, since their peak production, is designed for only 12 years since the discovery.
\end{abstract}

Keywords: Productive Chain, Regional Development, Pre-salt, Sustainability Geographic.

\section{Introduction}

The current global scenario, under sustainability aspects, reflects the thinking reflected in the work of the Club of Rome in 1972, which indicated the reality of the scarcity of natural resources, considering the high rate of world population. With the emergence of "environmental crisis" a contemporary line of thought gained political space. Thus, current discussions about the future, considering, especially the development has been promoting joint socio-political in favor of sustainable growth, with relevance to the thoughts of Sachs (1993), which emphasizes the perspectives, 
social, economic, environmental, space and cultural sustainability, particularly considering the exploration of the Brazilian pre-salt, particularly considering the exploration of the Brazilian pre-salt, observed by outlays on research and technological development, since there will be high demand for technical training in logistics and risks of exploration.

\section{Purpose}

The objective of the research is in the discussion of the current global scenario, under sustainability aspects, considering a holistic vision of sustainability in the production chain in oil exploration pre-salt layer which in a way reflects the thinking of the work referenced in the Club of Rome in 1972 which indicated the reality of scarcity of natural resources, considering the high rate of world population. With the emergence of "environmental crisis", a contemporary line of thought gained political space.

Thus, the current discussions about the future, considering in particular the development have promoted socio-joint policies for sustainable growth, with relevance to the thoughts of Sachs (1993), which emphasizes the perspectives, social, economic, spatial, environmental and cultural sustainability.

\section{Methodology}

The methodology of the article provides a qualitative approach, based on literature search, design specification, aiming for a holistic supply chain to discuss the pre-salt layer, from the perspective of sustainability, with relevance to the logistics flow. The research was the period between 2005 and 2010, considering scientific publications that give context to the pre-salt exploration, and the relevance of complexity from their extraction and mainly for transport, given that the sustainability aspects refer to the deep thoughts, considering the of environmental events in recent years.

The research was defined as literature, with a descriptive design with a qualitative approach. In addition to scientific publications, to collect data, we also used the database of the Center for Research and Development (CENPES) considering, specially Petrobras's information, relevant to planning and exploration of technological advances in the layer of pre-salt.

\section{$4 \quad$ Results and Discussion}

As a result, it was found that since its discovery in 2006, the exploration of the presalt layer is highly complex, requiring high expenditure on research and technological development, especially in innovation, reaching its fullest designed for 12 years, considering the problems under the aspects of environmental, cultural, economic, and social space. 
Considering the extraction of oil in the country, with relevance to the pre-salt layer since its discovery in 2006, provides a holistic view of sustainability and understanding of its complexity, in particular its operation, but is concentrated phase of research and development.

The development maximized and designed for 12 years since its discovery in 2006, certainly, will require further large investments, mainly in Research, Development and Innovation (RD \& I), given the problems in aspects of environmental, cultural, economic, spatial and social considering the complexity and magnitude of the presalt exploration, surrounded by risks, among which we highlight the sustainability space, reflected mainly by logistical problems, considering the geography of the presalt, and environmental impacts involved in this process extraction, these impacts still purely theoretical knowledge, as represented at Table 1 , by stages since company foundation.

Table 1. Macro view of oil exploration in the country (Source: Authors adapted from Petrobras - Centre for Research and Development - CENPES 2010).

\begin{tabular}{ccc}
\hline $\begin{array}{c}\text { Years Since Petrobras } \\
\text { Foundation (1954) }\end{array}$ & $\begin{array}{c}\text { Goal of Production } \\
\mathbf{1 . 0 0 0 . 0 0 0} \text { barrels of oil per day }\end{array}$ & Chronology \\
\hline 45 & 45 & 1954 \\
27 & 27 & 1974 \\
22 & 22 & 1984 \\
12 & 12 & 2006 \\
\hline
\end{tabular}

Thus a holistic view represented in Fig. 1, under a projection of an economic standpoint, the pre-salt will be explored when likely to be high oil prices, yet in a not too distant future, low oil prices, due to the heating global or the development of cleaner sources of energy, can impair the operation of the pre-salt. Considering the array of sustainability, Lima and Fernandes (2009) a holistic view, make an approach on the oil sector, where the exploration and development stages express the relevance of the processes detailed below:

- Exploration and delineation of mineral deposits; Drilling, completion and production activities are concentrated in drilling the well and prepare it to receive the permanent production equipment for oil and gas;

- Refining and transportation back to the transfer of crude oil and gas production units for the derivatives, while the processing and distribution of natural gas cover asset of operations for the transport;

- Distribution and use of natural gas and other hydrocarbon fluids. 


\begin{tabular}{|c|c|c|c|c|c|}
\hline \multicolumn{6}{|c|}{ Matrix Sustainable Exploration of Pre-Salt } \\
\hline Sustainabilities & Resources & Industrialization & Product & $\begin{array}{c}\text { Market } \\
\text { (Internal \& External) } \\
\end{array}$ & $\begin{array}{c}\text { Consumer } \\
\text { Global }\end{array}$ \\
\hline Social & \multicolumn{5}{|c|}{$\begin{array}{l}\text { Training of human resources, employment generation and income } \\
\text { Corporate social responsibility involved intitutions }\end{array}$} \\
\hline Economic & \multicolumn{3}{|c|}{$\begin{array}{l}\text { Diversification of products: oil and oil products } \\
\text { Impact on the country's economic development, } \\
\text { contribution of the insertion of the country in the global } \\
\text { economy }\end{array}$} & $\begin{array}{l}\text { Meet internal } \\
\text { demands (self- } \\
\text { sustaining) }\end{array}$ & $\begin{array}{c}\text { Export: the } \\
\text { international } \\
\text { market }\end{array}$ \\
\hline Environmental & \multicolumn{2}{|c|}{$\begin{array}{c}\text { Extraction and Production: High spending } \\
\text { on research, considering the magnitude of } \\
\text { environmental impacts }\end{array}$} & \multicolumn{3}{|c|}{ Final Destination } \\
\hline Cultural & \multicolumn{5}{|c|}{$\begin{array}{c}\text { Oil Extraction: Expenditures on Research, Development and Innovation } \\
\text { Training of manpower direct local and migratory }\end{array}$} \\
\hline Spatial & \multicolumn{5}{|c|}{ Exploration, Production and Logistics Distribution considering the final consumers } \\
\hline \multicolumn{2}{|c|}{ Segment } & \multicolumn{2}{|c|}{ Materials and Relevant Equipaments } & \multicolumn{2}{|c|}{ Main Services } \\
\hline \multicolumn{2}{|c|}{ Exploration } & \multicolumn{2}{|c|}{$\begin{array}{l}\text { Seismographs, explosives and } \\
\text { mainframe computers }\end{array}$} & \multicolumn{2}{|c|}{$\begin{array}{l}\text { Geophysical survey and processing, } \\
\text { determining the profile of wells and } \\
\text { formation evaluation }\end{array}$} \\
\hline \multicolumn{2}{|c|}{ Drilling, completion and production } & \multicolumn{2}{|c|}{$\begin{array}{l}\text { Casing, flexible lines, and large turbine } \\
\text { generators and compressors }\end{array}$} & \multicolumn{2}{|c|}{$\begin{array}{c}\text { Drilling and cementing wells, chartering } \\
\text { of support vessels and submerged } \\
\text { launch lines }\end{array}$} \\
\hline \multicolumn{2}{|c|}{ Refining and transportation } & \multicolumn{2}{|c|}{$\begin{array}{l}\text { Large compressors and pumps, steam } \\
\text { turbines, furnaces towers, Vassos } \\
\text { pressure control and supervisory } \\
\text { systems }\end{array}$} & \multicolumn{2}{|c|}{$\begin{array}{l}\text { Maintenance, installation and assembly } \\
\text { of industrial plants, including pipelines } \\
\text { and storage systems }\end{array}$} \\
\hline
\end{tabular}

Fig. 1. Macro view of the productive chain of the pre-salt (Source: Authors, adapted from Lima and Fernandes (2009, p. 323)

\section{Development: Holistic Vision of Sustainability in the Production Chain in Oil Exploration Pre-Salt Layer}

\subsection{Geography of the Brazilian Pre-Salt Layer}

Geographically the pre-salt layer, covers part of the north coast of São Paulo, with a huge reservoir of oil and natural gas, also present in the Santos, Campos and Espirito Santo, and presents a macro view with coverage in the coastal region between the states of Santa Catarina and the Espirito Santo.

Above all, the challenges of the pre-salt exploration beyond the technological and environmental aspects, with the geographic relevance to sustainability, given the logistical problems of transport, considering the existence of a huge volume of natural gas, inherent in the process.

Variable important, observed particularly in the research of Lima (2008) which notes that there is a huge gap in about $350 \mathrm{~km}$ the continent almost making it impossible to flow of gas through pipelines across the ocean, and thus it is necessary to burn it at the base of production. So the question is: 
- Considering sustainability, which the environmental impacts of burning of these gases, as it focuses on issues related to the high release of gases?

- The same concept of sustainability with geographical approach, how will the distribution logistics of this production so far inland from the coast?

Thus, this paper discusses the holistic view of sustainability, considering the oil exploration of the pre-salt layer, in particular from the perspective of geography.

\subsection{Geography of Global Pre-Salt Layer}

According to a survey of Lima (2008, p. 4), it is estimated that "the pre-salt layer has an area of $112,000 \mathrm{~km}^{2}$.

Of this total, $41.000 \mathrm{~km}^{2}$ has been tendered and awarded. This layer is about $800 \mathrm{~km}$ long and in some areas, $200 \mathrm{~km}$ wide, "considering the reserves in Brazil, located at 350 kilometers of coastline. And also, the pre-salt layer is located between five and seven thousand feet below sea level, it can reach up to two thousand feet thick,

\subsection{Challenges of Sustainable Development of the Environmental and Cultural Vision of Oil Supply Chain}

The concept of sustainable development is concatenated from the emergence of the environmental crisis in mid-1980. Currently, "[...] is closely related to action strategies to implement a set of measures and therefore is not just a theoretical concept, but only instrumental". (BARRETO, 2001 cited in Fernandes et al. 2007, p. 15).

Sachs (1993) describes the cultural sustainability, assumes the role of relevance in the process of regional sustainable development, considering the roots of indigenous models of modernization, especially the regulatory processes of continuous improvement.

Considering the approach of Jacobi (1999), "the issue of sustainability is, in this end of century, a central role in the reflection on the dimensions of development and alternatives that are configured" in a way, "[...] the social and environmental context that characterizes contemporary societies reveals that the impact of humans on the environment "[...] is becoming increasingly complex, both in quantitative and qualitative terms." (JACOBI, 1999, p. 175, emphasis added).

In the same context, recent research by Rodrigues (2010, p. 26) states that no doubt "one of the challenges faced by the Brazilian Petroleum Company (Petrobras), the exploration of oil in the pre-salt is the great amount of associated natural gas."

Rodrigues (2010), this same approach, reveals that the gas transported by pipeline, by the ocean, considering the enormous distance, it would be economically unviable, and also contextualizes, in his research that an alternative would be burning even in the very basis of production, where, however, would encounter another aggravating 
factor, the production of pollutant gases on a large scale, versus the environmental dimension as defined: "The environmental dimension is focused on a set of actions that aim to prevent or mitigate harm arising from the development process." The solution is not in the suppression of development actions, but the adoption of forms of management that are intended to use not predatory the planet's resources. (CARVALHO, 2005, p. 49).

Considering the magnitude of the complex technological, and as their own definitions of the Brazilian Petroleum (Petrobras), initially for oil exploration in the pre-salt, several alternatives were suggested techniques in relation to excess gas inherent in the process, among which stands out:

- The technologies of the transformation of natural gas for transportation in lieu of using pipelines, which would involve high costs, economically unfeasible;

- Another important variable defined as a challenge to be considered in the process of extracting the pre-salt, is the cultural sustainability with a focus on training of human resources that are necessary for the production. At the same focus, Fraga (2008), estimated that 110 000 professionals will be needed to attend this demand.

But how to meet this demand for human resources?

The technological absorption capacity can be defined by the observations of Cohen and Levinthal (1990), considering that this concept can be understood since it has the ability to recognize the value of new knowledge, which is extremely necessary that assimilation.

This learning process inherent in technological absorptive capacity is of fundamental importance, but there is a learning curve - learning curve, that is, time is a valuable expenditure necessary in the absorption of technological knowledge is considered as another variable in process operation of the pre-salt. In this approach, although innovative capacity of enterprises depends directly from their capital borderline intellectual, and how they are structured, considering a range of variables such as geographic location, its investments in RD \& I, this same perspective, Sveiby (1998, p. 24), emphasizes that the so-called "knowledge organizations" are those characterized by having few tangible assets and their intangible assets much more valuable than their tangible assets.

And According to Stewart (1998, cited by ANTUNES; MARTINS, 2007, p. $6), "[\ldots]$ tangible assets contribute much less to the value of your product or service end of that intangible assets." Whereas the pre-salt extraction requires much more than prior knowledge, and requires investment in large scale research, particularly De Negri (2006, p. 108) in their study identified some factors to measure the ability absorption of the companies, reducing the learning curve.

This requires also was observed by Da Silva; Oliveira; Silva (2011, p. 4), by Factors determining the absorption capacity of technology companies.

Considering the operational know-how, it is clear that Petrobras operates $23 \%$ of global production in deep water, being independent of this framework, the exploration of the pre-salt, goes further, and should be considered as new business to a new 
market, given that alternative fuels increasingly gaining space, not to mention the exploitation of "black gold", the shortage will lead to the same.

Another large and important variable to be considered, without doubt are the environmental challenges and their possible impacts, given recent events, where you can highlight the accident by British Petroleum - BP in mid-2010.

The accident with the Deep-water, the platform operated by British Petroleum (BP) in the Gulf of Mexico undoubtedly produced much more than the leak of five thousand barrels of oil per day. In addition to the environmental consequences, with a spot of more than $50 \mathrm{~km}$ in length, the accident did the British company losing $\$ 25$ billion in market value and raised some questions, among which are:

- Considering the magnitude of environmental accident, on an international scale, to what extent the operation of drilling in high seas has been affected?

- While environmentalists around the world to question this type of operation off-shore, pointed to by experts as one of the safest in the production chain of oil black, accidents such as the Gulf of Mexico in 2010, are increasingly rare?

Considering the problems of distribution logistics, with special emphasis on transport, as found in the survey of Rodrigues (2010), it is important to note that other studies reveal that large oil spills at sea occurred more frequently and were more harmful the environment during transport of the product and not on his farm, the scene observed that the representation in Table 2 .

Table 2. Ranking of the 10 largest oil spill accidents at sea (Source: The International Tanker Owners Pollution Federation - ITOPF 2010)

\begin{tabular}{cccc}
\hline Date & Ship & Local & $\begin{array}{c}\text { Leak } \\
\text { (Ton. } \text { 1000) }\end{array}$ \\
\hline 1979 & Atlantic Empress & Tobago & 278 \\
\hline 1991 & ABT Summer & Angola & 260 \\
\hline 1983 & Castillo de Bellver & África do Sul & 252 \\
\hline 1978 & Amoco Cadiz & França & 223 \\
\hline 1991 & Haven & Itália & 144 \\
\hline 1988 & Odyssey & Canadá & 132 \\
\hline 1967 & Torrey Canyon & Reino Unido & 119 \\
\hline 1976 & Urquiola & Espanha & 100 \\
\hline 1977 & Hawallian Patriot & Honolulu & 95 \\
\hline 1979 & Independenta & Turquia & 95 \\
\hline
\end{tabular}


Considering the approach of the problems of distribution logistics, Gouveia (2010, p. 35) also notes that: Two Petrobras projects developed by teachers in the UNESP campus of the North Coast, in San Vicente, and approved by Promimp, seek to ensure rapid and efficient accident associated with extraction and production of oil in the Santos Basin. One proposes the installation of filters made of activated charcoal in the bottom of the sea, for the absorption of oil in case of leaks in vessels or platforms.

The other aims to implement a regional referral center for study control and monitoring of aquatic and terrestrial environments, in order to protect the biodiversity of the regions explored.

The Petrobras itself (2011) states that the challenges are to find ways to provide efficient and especially in finding logistics solutions for this energy source more and more distant. However the flow of production is still a topic in depth discussion, given the risks and costs involved, but is already approaching the reinjection of gas into the soil. Gouveia (2010, p. 33) also reveals that, "[...] the logistics organization is another bottleneck: How to support the transport of people and cargo and supply of diesel for operation of the rigs and production platforms?

The distance of the pre-salt accumulations from the coast is about $300 \mathrm{~km}$, which is the maximum range of flight autonomy of most helicopters.

Petrobras's own research shows that the solution may be the construction of intermediate bases, installed between the point of production and shipment of resources, providing better techno-economic feasibility for the process of extracting the pre-salt. However the search for optimal solution for the scenario of the pre-salt, Petrobras has signed partnerships with institutes and universities stand out among the fifteen Brazilian universities:

- Universidade Estadual Paulista (UNESP),

- São Paulo University (USP),

- State University of Campinas (UNICAMP),

- Universidade Federal de São Carlos (UFSCar),

- Federal University of Rio de Janeiro (UFRJ),

- Universidade Federal da Bahia (UFBA),

- Institute of Technological Research of São Paulo (IPT), among others.

\section{$6 \quad$ Practical Implications}

This study aims to contribute about thinking in logistics and transportation of petroleum considering the extraction of the same in the pre-salt layer, where large distances must be considered in order to avoid impacts, particularly environmental. 


\section{$7 \quad$ Value of the Paper}

The issue of sustainability, in particular the geographical, directly affects the operation of the pre-salt, considering especially the distances involved, the logistics of transportation and distribution of products, and especially the disposal or reuse of excess natural gas, which is inherent extraction, which somehow has encouraged large-scale surveys in order to obtain effective responses, and provides technicaleconomic in exploring the viability of the pre-salt layer.

An aggravating factor seen in the research, especially considering the formation of intellectual capital, will be the peak of production that require a highly qualified man power, considering that there will be a learning curve, impacting the absorption curve of technology. How is the timing between research and development, innovation and application themselves of the resources involved?

Considering the presence of foreign corporations in the process of exploitation of the pre-salt layer, as is being conducted to integrate technology, considering the learning curve? Given the magnitude of the project, current events and oil spill at sea.

Considering all the variables considered in this and other research, the question is: Are we truly prepared? Thus, the main result was observed in research that somehow the oil and natural gas should and must have a holistic vision for the future of energy, considering the scarcity of resources and innovation in the search for sustainable alternatives.

In this approach, the coming decades are likely to be the most challenging energy history of the planet, especially considering the recent scientific studies that point to alternative fuels, in a more sustainable world in fact.

\section{References}

1. Carvalho, J.C.A.: Desenvolvimento Sustentável e Turismo: O caso dos Lençóis Maranhenses. Dissertação de Mestrado. Escola Brasileira de Administração Pública e de Empresas- Fundação Getúlio Vargas. Rio de Janeiro (2005)

2. Cohen, W.M., Levinthal, D.A.: Absorptive capacity: a new perspective on learning and innovation. Administrative Science Quarterly 35(1), 128-152 (1990)

3. Fernandes, F.R.C., et al.: Grandes minas e comunidade: algumas questões conceituais. Rio de Janeiro. CETEM/MCT, 58p. (2007)

4. Fraga, C.T.C.: O pré-sal e seus desafios. Audiência Pública no Senado Federal. Out. (2008)

5. Da Silva, A.L., Silva, J.L.G., Oliveira, E.A.A.Q.: Geografia da Inovação Industrial: uma análise da microrregião de são José dos Campos - SP. In: XII Mostra de Pós-Graduação, Internacionalização da Universidade: desafios no cenário global, Taubat (2011)

6. Gouveia, F.: Tecnologia nacional para extrair petróleo e gás do pré-sal. Conhecimento \& Inovação 6(1), 30-35 (1984) ISSN 1984-4395

7. Jacobi, P.: Meio Ambiente e Sustentabilidade. In: CEPAM Fundação Professor Faria Lima. O Município no Século XXI: Cenários e Perspectivas, Especial, São Paulo (1999)

8. Lima, J.P.R., Fernandes, A.C.: Demandas e ofertas tecnológicas em economias retardatárias: anotações a partir de dois segmentos econômicos no Nordeste brasileiro. Revista Brasileira de Inovação, Rio de Janeiro 8, 303-340 (2009) 
9. Lima, P.C.R.: Os desafios, os impactos e a gestão da exploração do pré-sal. Câmara dos Deputados (2008), Disponível em:

http: / / www.bd. camara.gov.br/bd/handle/bdcamara/984 (acesso em: September 22, 2011)

10. Antunes, M.T.P., Martins, E.: Gerenciando o capital intelectual: uma proposta baseada na controladoria de grandes empresas brasileiras. Revista de Administração Eletrônica da UFRGS (READ), Porto Alegre, edição 3(55) (January/Abr 2007)

11. OSLO MANUAL. Proposed guidelines for collecting and interpreting technological innovation data. Paris: OECD: Statistical Office of the European Communities (1997)

12. PETROBRAS. Disponível em: http: / / www.petrobras.gov.br/pt/ energia-e-tecnologia/tecnologia-e-pesquisa/ diversificando-os-produtos (acesso em: October 02, 2011)

13. PETROBRAS. Centro de Pesquisas e Desenvolvimento - CENPES (2010)

14. PROVEDOR GOOGLE. Disponível em, http: / / www.google.com/imagens / pré-sal (acesso em: September 27, 2011)

15. Rodrigues, R.C.: Pré-sal: desafios tecnológicos. Revista: Conhecimento \& Inovação 6(1), 26-27 (2010) ISSN 1984-4395

16. Sachs, I.: Estratégias de transição para o século XXI - desenvolvimento e meio ambiente. Studio Nobel/Fundap, São Paulo (1993)

17. Sveiby, K.E.: A Nova Riqueza das Organizações: gerenciando e avaliando patrimônios de conhecimento. Tradução de Luiz Euclides T. F. Filho. Campus, Rio de Janeiro (1998) 